\title{
SOLVENT-FREE MICROWAVE EXTRACTION OF ESSENTIAL OIL FROM DRIED BASIL (Ocimum basilicum L.) LEAVES
}

\author{
Heri Septya Kusuma1,* , Ditta Kharisma Yolanda Putri ${ }^{1}$, \\ Intan Ekawati Puspa Dewi ${ }^{1}$, Mahfud Mahfud ${ }^{1}$
}

https://doi.org/10.23939/chcht12.04.543

\begin{abstract}
In this study, the extraction of essential oils from basil leaves by solvent-free microwave extraction (SFME) was conducted. The effect of some parameters of SFME method on the basil oil yield was determined. The obtaining results were compared to those obtained via microwave hydrodistillation (MHD) method. It was shown that SFME method provides higher yield and faster extraction time. Using GC-MS analysis it was found that basil oil has the highest content of E-citral and Z-citral. The optimal operating conditions for the basil oil extraction were determined.
\end{abstract}

Keywords: Ocimum basilicum L., solvent-free microwave extraction, microwave hydrodistillation, basil oil, citral.

\section{Introduction}

Indonesia has many and varied natural resources. Among that biodiversity, there are plants that produce essential oils which have not yet been fully utilized. Currently, Indonesia has 40-50 types of plants that can produce essential oils that are traded in the world, but only some of them enter the world market, including patchouli [1-2], lemongrass [3], cloves [4], jasmine [5], ylang-ylang [6], eucalyptus [7], cajuput [8], sandalwood [9], and vetiver [10].

Among the variety of plants that can produce essential oils, there are some species that still need to be developed such as essential oils from basil (Ocimum basilicum L.). It has a variety of benefits and its economic value will be higher after processing. Currently, basil leaves are only used as salads, vegetable, and supplementary materials in cooking. In a traditional medicine, basil is used to treat fever, laxative of breast milk and nausea [11]. Besides other benefits of basil, it has been used as a medicine to cure several diseases such

\footnotetext{
${ }^{1}$ Department of Chemical Engineering, Faculty of Industrial Technology,

Institut Teknologi Sepuluh Nopember, Surabaya, Indonesia 60111

*heriseptyakusuma@gmail.com

(c) Kusuma H., Putri D., Dewi I., Mahfud M., 2019
}

as headache, cough, diarrhea, constipation, skin diseases, worm disease, and kidney failure.

The extraction of essential oils from basil today in general is still done by using conventional methods such as hydrodistillation, steam-hydrodistillation and steam distillation. These conventional methods generally produce smaller yields, require high cost and the extraction time is relatively long. Therefore, in this study, the extraction of essential oils from basil leaves by solvent-free microwave extraction (SFME) methods was conducted. In addition, the effect of some parameters on SFME method will be studied. Until now there were no studies that discuss basil oil extraction by SFME method and the effect of its parameters on the oil yield.

\section{Experimental}

\subsection{Plant M aterials}

Dried basil (Ocimum basilicum L.) leaves were collected from Surabaya, East Java, Indonesia. The leaves were chopped to the size of $0.5,1.5$ and $3.0 \mathrm{~cm}$ and stored at room temperature until required.

\subsection{Solvent-Free Microwave Extraction of Basil Oil}

We used a microwave oven (EMM-2007X, Electrolux, 201 , maximum delivered power of $800 \mathrm{~W}$ ) with wave frequency of $2450 \mathrm{MHz}$. The dimensions of the PTFE-coated cavity of the microwave oven were $46.1 \times 28.0 \times 37.3 \mathrm{~cm}$. The microwave oven was modified by drilling a hole at the top. A round bottom flask with a capacity of $1000 \mathrm{ml}$ was placed inside the oven and was connected to the three-way adapter and Liebig condenser through the hole. Then, the hole was closed with PTFE to prevent any loss of heat inside [12].

In a typical SFME procedure performed at atmospheric pressure, the specimens of various sizes $( \pm 0.5$, \pm 1.5 and $\pm 3.0 \mathrm{~cm}$ ) and feed-to-distiller ratios $\left(\mathrm{F} / \mathrm{D}=0.05,0.10\right.$ and $\left.0.15 \mathrm{~g} \cdot \mathrm{ml}^{-1}\right)$ were wetted before extraction by soaking in distilled water for $30 \mathrm{~min}$, and then 
the excess of distilled water was removed. The wetted material was placed in a 11 flask. The microwave oven was operated at four power levels $(100,240,380$ and $540 \mathrm{~W})$ for $1 \mathrm{~h}$. To remove water, the extracted basil oil was dried over anhydrous sodium sulfate, weighed and stored in amber vials at $277 \mathrm{~K}$ until used for analysis [13]. The yield of basil oil $(\%, w / w)$ was calculated as the ratio between weights of extracted basil oil and dried basil leaves.

\subsection{M icrowave Hydrodistillation of Basil Oil}

Microwave hydrodistillation was performed similar to SFME. $40 \mathrm{~g}$ of dried basil leaves and $400 \mathrm{ml}$ of distilled water (plant material-to-water ratio is 0.10 ) were placed into 11 flask with a Liebig condenser, and basil oil was extracted for $180 \mathrm{~min}$ (until no more essential oil was obtained). Basil oil was collected in amber vials, dried under anhydrous sodium sulfate and stored at $277 \mathrm{~K}$.

\subsection{Analyses}

The components of the basil oil were identified by GC-MS analysis [14]. GC-MS analysis was performed on Agilent 6890 GC, copuled to an Agilent 5973A MSD.

For SEM analysis the specimens were freeze-dried, fixed on the specimen holder with aluminium tape and then sputtered with gold. All the specimens were examined using Inspect-S50, under vacuum conditions and the accelerating voltage of $10 \mathrm{kV}$ [15].

\section{Results and Discussion}

\subsection{The Effect of SFME Parameters on Basil Oil Extraction}

Effect of microwave power on the yield of basil oil

Microwave power in the extraction process has an effect on the yield of the produced basil oil (Fig. 1). One

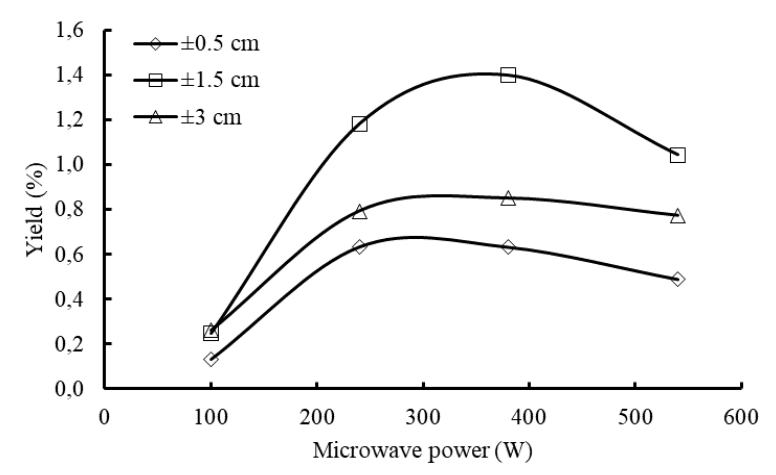

a) can see from Fig. 1, that there is an increasing trend of yields as the microwave power increases. The greater the energy received by the material to be converted into heat, the more the yield of obtained basil oil. However, the declining trend of the yield at the microwave power of $540 \mathrm{~W}$ can also be seen. Considering that, the microwave power was too high which caused faster evaporation rate. This might cause degradation of the material that can actually decrease the obtained yield and could cause basil oil composition to become damaged. Therefore, from the four variables of the microwave power that are shown in Fig. 1, the best microwave power to produce the optimum basil oil yield was found to be $380 \mathrm{~W}$.

\section{basil oil}

Effect of feed-to-distiller (F/D) ratio on the yield of

Besides the microwave power, F/D ratio also affects the basil oil extraction (Fig. 2). The highest yield is acheived at $\mathrm{F} / \mathrm{D}=0.05 \mathrm{~g} / \mathrm{ml}$. This is occured because at the smallest ratio (density factor is not too high), basil can be extracted well. The density factor of the material is the ratio between the mass of material and the volume capacity of used distiller. The used F/D ratio has relations with the density and the amount of raw materials that are in the distiller, so that the extraction process and evaporation of basil oil could be more optimized.

It can be seen from Fig. 2 that the resulting yield decreases with increasing F/D ratio. The reason is the fact that the increase in F/D ratio increases density in the distiller, therefore causes the difficulties for essential oil to be extracted. At F/D ratio of $0.15 \mathrm{~g} / \mathrm{ml}$, the obtained yield is lower than at other F/D ratios; this is caused by the fact that the density factor at F/D ratio of $0.15 \mathrm{~g} / \mathrm{ml}$ is high (the mass of used raw material (dry basil leaves) is already too much and almost fulfill the distiller). So, it is difficult for vapor to penetrate the raw material to diffuse the basil oil molecules out of the material. The density of the material is closely linked to the intermaterial space in the distiller. The high density of materials can cause the formation of steam line "rat holes" that can reduce yield and quality of basil oil [16].

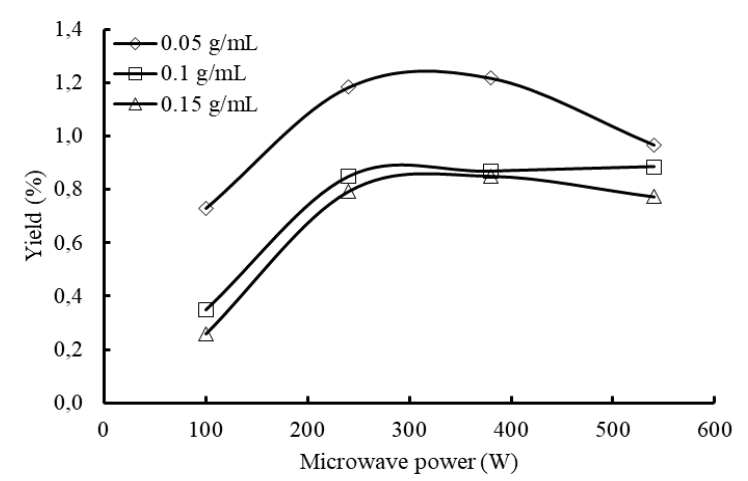

b)

Fig. 1. The effect of microwave power on the basil oil yield at different sizes of material (a) and F/D ratios (b). For (a) the $F / D=0.15 \mathrm{~g} / \mathrm{ml}$; for (b) the material size $\pm 3 \mathrm{~cm}$ 


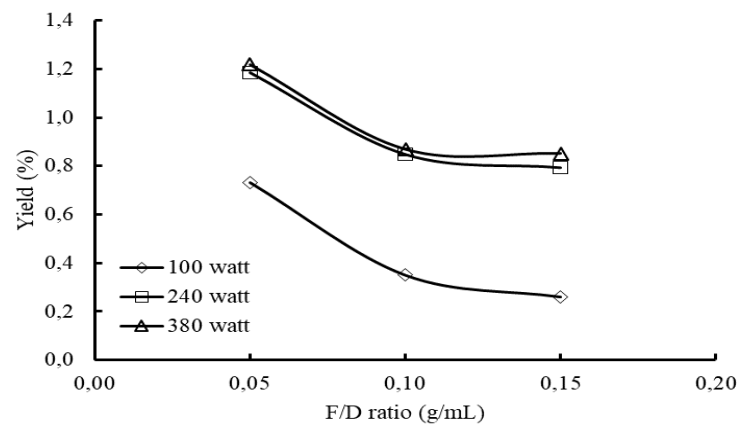

a)

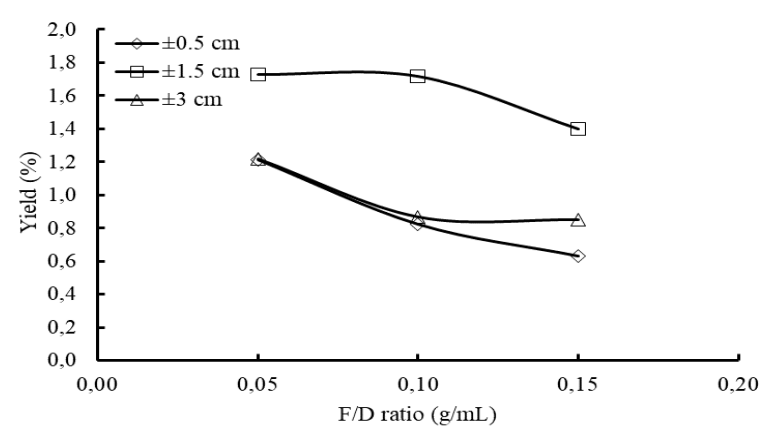

b)

Fig. 2. The effect of F/D ratio on the basil oil yield at different microwave powers (a) and material sizes (b). For (a) the material size $\pm 3 \mathrm{~cm}$; for (b) the microwave power $380 \mathrm{~W}$

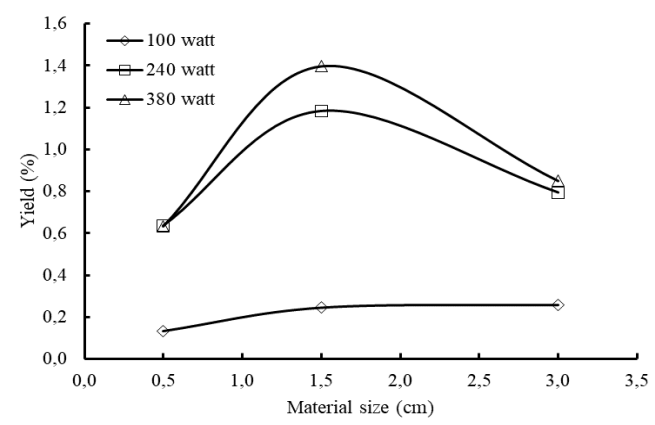

a)

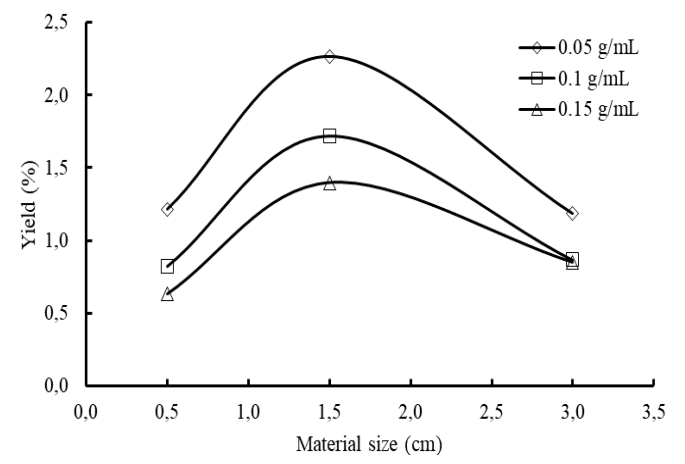

b)

Fig. 3. The effect of material size on the basil oil yield at different microwave powers (a) and F/D ratios (b). For (a) $\mathrm{F} / \mathrm{D}=0.15 \mathrm{~g} / \mathrm{ml}$; for (b) the microwave power $380 \mathrm{~W}$

Water content of dried basil leaves

\begin{tabular}{|c|c|c|}
\hline Material conditions & Material size, $\mathrm{cm}$ & Water content, $\%$ \\
\hline \multirow{3}{*}{ Dry } & \pm 3 & $9.853 \pm 0.971$ \\
\hline & \pm 1.5 & $6.774 \pm 0.726$ \\
\hline & \pm 0.5 & $7.879 \pm 0.396$ \\
\hline \multirow{3}{*}{ Dry (soaked) } & \pm 3 & $83.319 \pm 1.896$ \\
\hline & \pm 1.5 & $84.270 \pm 1.799$ \\
\hline & \pm 0.5 & $81.557 \pm 3.127$ \\
\hline
\end{tabular}

\subsection{The Comparison of Basil Oil Extraction by Microwave Hydrodistillation and Solvent-Free Microwave Extraction M ethods}

The increase of the basil oil yield along with increasing extraction time at SFME method can occur because a heating using microwave has selective and volumetric properties. The meaning of selective properties is that microwave radiation can directly penetrate the distillation flask (distiller) which is transparent, so the radiation can be directly absorbed by the material and solvent. The meaning of volumetric properties is that the heating is evenly distributed and occurs directly on the materials; so the heating can take place more quickly. This allows to obtain high yield of basil oil at lower extraction time when the extraction is done by SFME compared with conventional methods.

In general, the extraction process has three important stages: equilibrium phase, transition phase and diffusion phase. In equilibrium phase, displacement of the substrate contained in the outer layer of the matrix occurs. The movement of the substrate takes place at constant rate. Then in the transition phase there is a mass transfer that occurs by convection and diffusion. Finally, a diffusion phase, which has slow extraction rate, is characterized by the release of the extract through 
diffusion mechanism. In the extraction process, the diffusion phase is often considered as the limiting step [17].

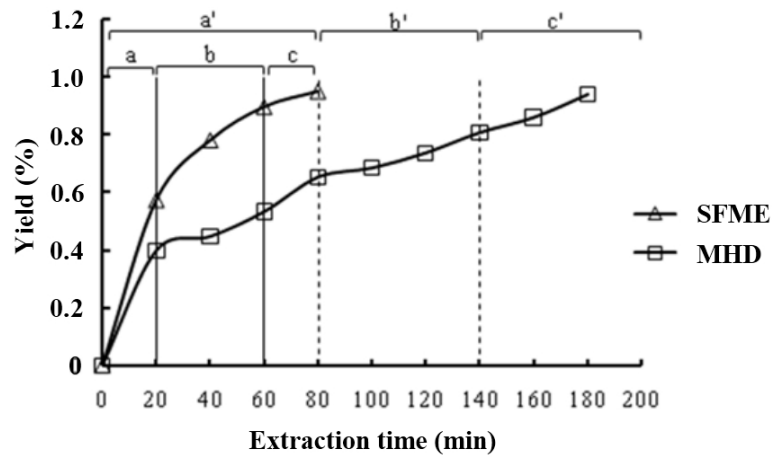

Fig. 4. The comparison of basil oil extraction by MHD and SFME methods $\left(\mathrm{a}=\mathrm{a}^{\prime}=\right.$ equilibrium phase; $\mathrm{b}=\mathrm{b}^{\prime}=$ transition phase $; \mathrm{c}=\mathrm{c}^{\prime}=$ diffusion phase $)$

In basil oil extraction by SFME, the extraction time is one of the advantages and factors that need to be considered. In general, the longer extraction time cause the higher obtained yield. However, with the longer extraction time the obtained yield may be smaller [18]. The comparison of basil oil extraction by MHD and SFME can be seen in Fig. 4. It is shown that MHD method requires longer extraction time to reach equilibrium phase compared to SFME method, which is $80 \mathrm{~min}$. On the other hand, using SFME method, a diffusion phase has been reached for 80 min. Besides, Fig. 4 shows that at basil oil extraction by SFME method almost the same yield $(0.95 \%)$ with shorter extraction time can be obtained compared to MHD method $(0.94 \%)$. This proves that SFME method is more effective compared to MHD method.

\subsection{GC-MS Analysis}

To find out the components contained in basil oil, analysis is done using gas chromatography-mass spectrometry (GC-MS) [13]. This analysis is not only used to identify the components contained in basil oil, but also to determine levels for each component. From Table 2 it can be seen that the basil oil from dried basil leaves extracted by SFME method contained 55 components with the highest percentage of E-citral $32.64 \%$ and Z-citral $26.49 \%$. From these results it can be seen that the type of basil used in this research is citral type. This is according to the research conducted by Mondello et al. [1], in which the components of basil oil for citral type is geranial (E-citral) $33.70 \%$ and neral (Z-xitral) $27.90 \%$.

Table 2

Components contained in basil oil extracted by SFME method (microwave power $380 \mathrm{~W}, \mathrm{~F} / \mathrm{D}$ ratio $0.175 \mathrm{~g} / \mathrm{ml}$ and material size $\pm 3 \mathrm{~cm}$ )

\begin{tabular}{|c|c|c|c|}
\hline No. & R.T., min & Compound & Area, \% \\
\hline 1 & 2 & 3 & 4 \\
\hline & & Monoterpenes & \\
\hline 1 & 5.565 & $\beta$-Ocimene & 0.421 \\
\hline 2 & 8.176 & trans-Chrysanthemal & 0.590 \\
\hline 3 & 10.449 & Camphene & 0.239 \\
\hline 4 & 14.359 & Spiro[4,5]decane & 0.845 \\
\hline & & Oxygeneted Monoterpenes & \\
\hline 5 & 7.201 & D- $(+)$-Fenchone & 0.158 \\
\hline 6 & 7.453 & Linalool L & 4.703 \\
\hline 7 & 8.002 & cis/cis-Photocitral & 0.176 \\
\hline 8 & 8.916 & Isoestragol & 0.280 \\
\hline 9 & 9.761 & Z-citral & 26.491 \\
\hline 10 & 9.857 & Piperiton & 0.216 \\
\hline 11 & 10.937 & Cyclobutanol, 1-ethenyl-2-(2-methyl-1-propenyl)-, cis- & 0.424 \\
\hline 12 & 11.128 & Epenone & 0.160 \\
\hline 13 & 11.825 & cis-Limonene oxide & 0.084 \\
\hline 14 & 11.991 & Chrysanthenone & 0.197 \\
\hline 15 & 14.220 & $p$-Menth-1(7)-en-9-ol & 0.091 \\
\hline 16 & 14.577 & Tanacetone & 0.089 \\
\hline 17 & 19.654 & Perillen & 0.237 \\
\hline & & Sesquiterpenes & \\
\hline 18 & 10.275 & E-citral & 32.640 \\
\hline 19 & 11.102 & (Z)- $\beta$-farnesene & 0.627 \\
\hline 20 & 11.459 & Copaene & 0.207 \\
\hline 21 & 11.668 & $\beta$-Elemene & 0.409 \\
\hline 22 & 11.903 & $\alpha$-Gurjunene & 0.239 \\
\hline 23 & 12.078 & $\beta$-Caryophyllene & 4.929 \\
\hline 24 & 12.156 & $\begin{array}{l}\text { 1H-Cyclopenta[1,3]cyclopropa[1,2]benzene, } 2,3,3 \mathrm{a} \alpha, 3 \mathrm{~b} \alpha, 4,5,6,7 \text {-octahydro- } \\
4 \alpha \text {-isoprophyl- } 7 \beta\end{array}$ & 0.080 \\
\hline
\end{tabular}


Table 2 (continued)

\begin{tabular}{|c|c|c|c|}
\hline 1 & 2 & 3 & 4 \\
\hline 25 & 12.217 & $\alpha$-Bergamotene & 2.201 \\
\hline 26 & 12.304 & $\begin{array}{l}\text { Cyclohexene, 3-(1,5-dimethyl-4-hexenyl)-6-methylene, } \\
\text { s-(R@, s@)]- }\end{array}$ & 0.232 \\
\hline 27 & 12.487 & $\alpha$-Humulene & 1.481 \\
\hline 28 & 12.565 & $\beta$-Sesquiphellandrene & 0.122 \\
\hline 29 & 12.739 & $\gamma$-Cadinene & 0.098 \\
\hline 30 & 12.826 & Germacrene-D & 1.987 \\
\hline 31 & 13.018 & $\begin{array}{l}\text { Naphthalene, 1,2,3,4a,5,6,8a-hexahydro-4,7-dimethyl-1-(1-methylethyl)-, } \\
(1 \alpha, 4 \mathrm{a} \alpha, 8 \mathrm{a} \alpha) \text { - }\end{array}$ & 0.238 \\
\hline 32 & 13.192 & $\begin{array}{l}\text { Naphthalene, } 1,2,3,4,4 \mathrm{a}, 5,6,8 \mathrm{a}-\text { octahydro-7-methyl-4-methylene-1-(1- } \\
\text { methylethyl)-, }(1 \alpha, 4 \mathrm{a} \beta, 8 \mathrm{a} \alpha) \text { - }\end{array}$ & 0.148 \\
\hline 33 & 13.297 & Naphthalene, 1,2,3,5,6,8a-hexahydro-4,7-dimethyl-1-(1-methylethyl)-, (1S-cis)- & 0.652 \\
\hline 34 & 13.532 & cis- $\alpha$-Bisabolene & 4.660 \\
\hline 35 & 16.798 & $\begin{array}{l}\text { Dihydro-Neoclovene- (II) } \\
\text { Oxygenated Sesquiterpenes }\end{array}$ & 0.091 \\
\hline 36 & 13.680 & Caryophyllene oxide & 3.693 \\
\hline 37 & 14.847 & $\begin{array}{l}\text { 1H-Benzocyclohepten-7-ol, 2,3,4,4a,5,6,7,8-octahydro-1,1,4a, 7-tetramethyl-, cis- } \\
\text { Other Oxygenated Compounds }\end{array}$ & 0.177 \\
\hline 38 & 5.546 & Methyl heptenone & 0.631 \\
\hline 39 & 8.089 & Dicyclopropyl ketone & 0.205 \\
\hline 40 & 8.402 & (S,E)-3-Methyl-2-methylene-4-hexenal & 1.425 \\
\hline 41 & 8.551 & Rosefuran epoxide & 0.150 \\
\hline 42 & 8.681 & Cyclopentanol, 1-(methylenecyclopropyl)- & 1.938 \\
\hline 43 & 10.728 & 2,6-Octadienoic acid, 3,7-dimethyl-, methyl ester & 0.167 \\
\hline 44 & 10.850 & Dihydronopol & 0.201 \\
\hline 45 & 11.242 & Neryl acetate & 0.256 \\
\hline 46 & 11.276 & Caryophyllic acid & 0.159 \\
\hline 47 & 11.407 & Methyl trans-2-butenoate & 0.784 \\
\hline 48 & 11.512 & Geranyl acetate & 0.557 \\
\hline 49 & 11.538 & cis-3-Hexenyl Lactate & 0.326 \\
\hline 50 & 14.682 & Spiro[adamantane-2,5'-[1.2]dioxolan]-3'-one, 4'-methylene- & 0.204 \\
\hline 51 & 16.031 & Benzyl benzoate & 1.833 \\
\hline 52 & 17.094 & Benzyl salicylate & 0.171 \\
\hline 53 & 17.999 & Geranyl benzoate & 0.135 \\
\hline 54 & 19.393 & 4,6-bis(4'-Methylpent-3'-en-1'-yl)-6-methylcyclohexa-1,3-diene-1-carbaldehyde & 0.398 \\
\hline 55 & 19.724 & Cyclohexanone, 3-(4-hydroxy-3-methyl-2-butenyl)-2,2,6-trimethyl-, [3R-[3R*(E)]]- & 0.148 \\
\hline & 2.095 \\
\hline \multicolumn{3}{|c|}{$\begin{array}{l}\text { Monoterpenes } \\
\text { Oxygenated Monoterpenes }\end{array}$} & 33.306 \\
\hline \multicolumn{3}{|c|}{ Sesquiterpenes } & 51.041 \\
\hline \multicolumn{3}{|c|}{ Oxygenated Sesquiterpenes } & 3.870 \\
\hline \multicolumn{3}{|c|}{ Other Oxygenated Compounds } & 9.688 \\
\hline
\end{tabular}

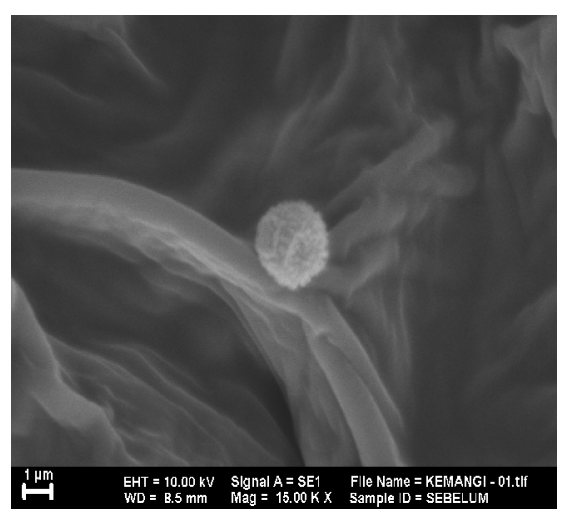

a)

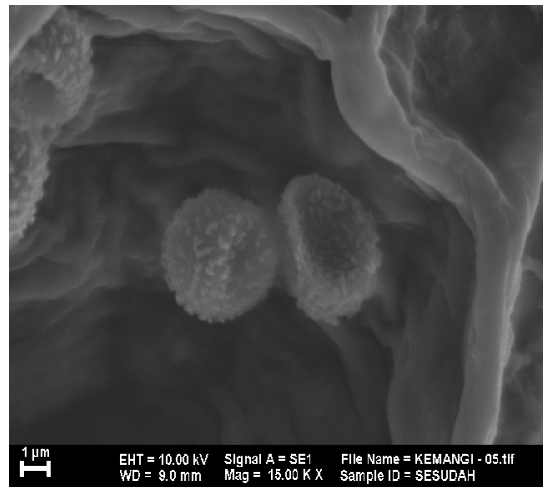

b)

Fig. 5. The SEM results of basil leaves before (a) and after (b) extraction by SFME method. Magnification of 15,000× 
The components contained in basil oil can be classified into several compounds such as monoterpenes, oxygenated monoterpenes, sesquiterpenes, oxygenated sesquiterpenes, other compounds, and other oxygenated compounds. The oxygenated compounds affect more the scent of essential oils compared with monoterpene compounds [15]. Based on GC-MS analysis, it is concluded that the content of oxygenated compounds in basil oil from dried basil leaves is $46.86 \%$. This indicates that basil oil obtained by SFME method has good scent.

\subsection{SEM Analysis}

Scanning electron microscopy (SEM) is an analysis used to determine the surface structure of a material. In this case the analyzed material is basil leaves before and after extraction. Based on Fig. 5, there are oil glands that are still intact (perfect form) at the cross of basil leaves before extraction. However, after the extraction process, the oil glands form was not perfect anymore because the essential oils contained in it have been drawn. In the sample of extracted basil leaves (Fig. 5b), oil glands form is just slightly concave and not damaged. This can be due to the high F/D ratio $(0.25 \mathrm{~g} / \mathrm{ml})$ of the used materials, so there is a possibility that the basil leaves will not be extracted perfectly (the density factor of materials).

\section{Conclusions}

Solvent-free microwave extraction (SFME) method can be used for extraction of basil oil. The optimum obtained basil oil yield by SFME method is equal to $1.73 \%$ (microwave power $380 \mathrm{~W}, \mathrm{~F} / \mathrm{D}$ ratio of $0.05 \mathrm{~g} / \mathrm{ml}$ and material size of $\pm 1.5 \mathrm{~cm}$ ). According to GC-MS analysis, basil oil has the highest content of E-citral and Zcitral. SFME method has advantages over previous method, such as microwave hydrodistillation (MHD), due to higher yield and faster extraction time.

\section{References}

[1] Kusuma H., Mahfud M.: AIP Conf. Proc., 2015, 1699, 050014. https://doi.org/10.1063/1.4938350

[2] Kusuma H., Altway A., Mahfud M.: J. Ind. Eng. Chem., 2018, 58, 343. https://doi.org/10.1016/j.jiec.2017.09.047

[3] Moncada J., Tamayo J., Cardona C.: Ind. Crops Prod., 2014, 54, 175. https://doi.org/10.1016/j.indcrop.2014.01.035
[4] Kapadiya S., Parikh J., Desai M.: Ind. Crops Prod., 2018, 112, 626. https://doi.org/10.1016/j.indcrop.2017.12.060

[5] Saripalle M.: World Dev. Perspect., 2016, 1, 12. http://dx.doi.org/10.1016/j.wdp.2016.05.004

[6] Burdock G., Carabin I.: Food Chem. Toxicol., 2008, 46, 433. https://doi.org/10.1016/j.fct.2007.09.105

[7] Rodrigues V., de Melo M., Portugal I., Silva C.: J. Supercrit. Fluids, 2018, 135, 263. https://doi.org/10.1016/j.supflu.2018.01.010 [8] Ismanto A. Kusuma H., Mahfud M.: IOP Conf. Ser.: Earth Environ. Sci., 2017, 101, 012014. https://doi.org/10.1088/17551315/101/1/012014

[9] Kusuma H., Mahfud M.: Int. Food Res. J., 2017, 24, 1697.

[10] Kusuma H., Altway A., Mahfud M.: IOP Conf. Ser.: Earth Environ. Sci., 2017, 101, 012015. https://doi.org/10.1088/17551315/101/1/012015

[11] Pitojo S., Kemangi dan Selasih. Ungaran: Trubus Agriwidya, 1996.

[12] Kusuma H., Syahputra M., Parasandi D. et al.: Rasayan J. Chem., 2017, 10, 861. https://doi.org/10.7324/RJC.2017.1031763 [13] Mahfud M., Putri D., Dewi I. et al.: Rasayan J. Chem., 2017, 10, 86. https://doi.org/10.7324/RJC.2017.1011562

[14] Kusuma H., Mahfud M.: RSC Adv., 2017, 7, 1336. https://doi.org/10.1039/c6ra25894h

[15] Ferhat M., Meklati B., Chemat F.: Flavour Fragr. J., 2007, 22, 494. https://doi.org/10.1002/ffj.1829

[16] Guenther E.: Essential Oils Volume IVB (in Bahasa Indonesia). Jakarta: Universitas Indonesia Press, 1990.

[17] Knox J.: Encyclopedia of Separation Science. Academic Press, Edinburgh 2000.

[18] Wang Y., You J., Yu Y. et al.: Food Chem., 2008, 110, 161. https://doi.org/10.1016/j.foodchem.2008.01.028

Received: November 04, 2017 / Revised: May 07, 2018 / Accepted: June 27, 2018

\section{МІКРОХВИЛЬОВА ЕКСТРАКЦІЯ БЕЗ РОЗЧИННИКА ЕФІРНИХ ОЛІЙ ІЗ ВИСУШЕНОГО ЛИСТЯ БАЗИЛІКУ (Ocimum basilicum L.)}

Анотація. За допомогою мікрохвильової екстракції без розчинника (SFME) проведено екстракцію ефірних олій з листя базиліка. Визначено вплив параметрів на вихід олії. Отримані результати порівнювали з результатами, отриманими методом мікрохвильової гідродистилячії (MHD). Показано, щуо SFME метод забезпечує більи високий вихід та зменшуе тривалість екстракиії. 3 використанням газової хроматографії-масової спектроскопії (GC-MS) було встановлено, щуо найбільший вміст в базилічній олії компонентів Е-цџитраль та Z-цฺитраль. Визначено оптимальні умови одержання базилікової олії.

Ключові слова: Осітит basilicum L., мікрохвильова екстракція без розчинника, мікрохвильова гідродистиляція; базилікова олія; ичитраль. 